\title{
POZYTYWIZM PRAWNICZY A ZASADA SŁUSZNOŚCI
}

\section{Opozycja „prawo pozytywne - prawo naturalne”}

Zasada słuszności, obok zasady sprawiedliwości czy uczciwości, stanowi kamień węgielny rozmaitych systemów prawnonaturalnych, gdzie jest punktem odniesienia dla konkretnych rozwiązań prawnych. Wszelkie koncepcje głoszące prymat prawa natury nad porządkiem prawa państwowego opierają się na zasadzie lex iniusta non est lex i uznają tezę, że prawo naturalne pełni funkcję walidacyjną w odniesieniu do praw państwowych. Filozofowie praw natury są wyznawcami poglądu, że prawa te mają byt bardziej realny i bardziej obiektywny charakter niż prawa państwowe. ${ }^{1}$ Wydaje się, że w ich opinii prawa natury to powszechniki, czyli uniwersalia - stałe i niezmienne, odwieczne i absolutne prawidła moralne, doskonały wzorzec, bliski platońskiej ,idei”, wszelkich praw państwowych.

Z kolei zwolennicy prawa pozytywnego to, programowo, nominaliści, nie uznający bytów powszechnych, odmawiający istnienia prawom naturalnym, w rozumieniu jusnaturalistów. Typowy pozytywista to przeciwnik istnienia powszechników, odrzucający tezę, że prawa natury wiążą prawodawcę w sposób absolutny. Mogą być dlań istotną wskazówką przy ustanawianiu praw, ale nie mają bezwzględnie imperatywnego charakteru; teoretycznie mógłby on zrezygnować $\mathrm{z}$ wcielenia ich do porządku prawnego. Prawa pozytywne obowiązują dlatego, że zostały ustanowione przez prawodawcę, a nie dlatego, że wpisują się w reguły prawa natury.

Klasyczny pozytywista prawniczy może zakładać, że ustanowienie prawa pozytywnego konstytuuje w danej społeczności moralność i że nie istnieje jakakolwiek konieczność określonego jej zdefiniowania. Może przyjąć, że jest ona względna, podlega zmianom; prawodawca jest władny, by ją w każdym czasie modyfikować czy nawet unieważnić. Nominalistyczny uniwersalizm poznawczy, cechujący przed-

1 A. Kozak, Trzy modele praktyki prawniczej, (w:) J. Stelmach (red.), Studia z filozofii prawa, t. 2, Kraków 2003, s. 150 . 
stawicieli pozytywizmu prawniczego, pozwala domniemywać, że dopuszczają oni wielość możliwych porządków prawnych, z których każdy byłby równie dobry jak inny, jeśli tylko pozwalałby na utrzymanie podstawowych celów państwa. Implikuje to założenie, że istnieć może wiele definicji „,sprawiedliwości”, a probierzem „prawdziwości" każdej z nich byłaby tylko ich zgodność z wykreowanym przez suwerena porząakiem prawnym.

U źródeł pozytywizmu prawniczego wymienia się zwykle dwa zjawiska: polemikę z koncepcjami prawa natury oraz scjentyzm - wysiłki zmierzające do zbudowania naukowego prawoznawstwa, zafascynowanie naukowością. Scjentyzm, doktrynę bujnie rozwijającą się $\mathrm{w}$ drugiej połowie wieku XIX i przyznającą nauce szczególne miejsce w kulturze, charakteryzowała szczególna postawa badawcza, wyrastająca z przekonania, że człowiek może być jako podmiot poznający całkowicie autonomiczny względem świata, który opisuje, że może badać go niejako „z zewnątrz".

Włączenie prawa w obszar zainteresowania scjentyzmu stało się możliwe dzięki powstaniu rozbudowanego aparatu biurokratycznego, w którym zrodziła się potrzeba „unaukowienia legislacji”, a także dzięki zakończonej właśnie wtedy recepcji prawa rzymskiego. Pojęcia prawne ukształtowane w starożytnym Rzymie były na uniwersytetach ówczesnej Europy przedmiotem żmudnej rekonstrukcji już od XI wieku, który to proces zakończył się właśnie w XIX stuleciu. Zrekonstruowana siatka pojęciowa prawa rzymskiego stała się podstawą przekonania dziewiętnastowiecznych prawników, że jej elementy - pojęcia prawne - mają charakter tak samo uniwersalny, niezależny od uwikłań kulturowych czy etycznych, jak kluczowe pojęcia nauk ścisłych. Przekonanie to było podstawą podjętej przez niemieckich jurystów próby zbudowania idealnego, uniwersalnego kodeksu cywilnego, przyczyniło się też w istotny sposób do ukształtowania się pozytywizmu prawniczego. Ówczesny prawnik - teoretyk miał do dyspozycji narzędzia analizy prawa, czyli treści rozkazu suwerena. Pierwsi pozytywiści wykazywali, że przedmiot ich badań ma charakter obiektywny, a samo badanie prawa jest działalnością stricte naukową.

Metoda, która znalazła tutaj zastosowanie zwana jest formalno-dogmatyczną; dogmatyzm odnosi się do uznania za prawo woli suwerena, formalizm zaś oznacza sposób poznawania prawa przez jego adeptów. Badanie prawa ma polegać wyłącznie na jego systematyzowaniu, strukturyzowaniu, wyróżnianiu poszczególnych pojęć. W obszarze stosowania prawa pierwsi pozytywiści także byli formalistami, sprowadzając wydawanie orzeczeń do szeregu operacji logicznych - sylogizmu prawniczego, który podobny był do sylogizmu logicznego. ${ }^{2}$ Pierwszą fazę rozwoju pozytywizmu prawniczego M. Zirk-Sadowski nazywa pozytywizmem pierwotnym, odróżniając ją wyraźnie od fazy drugiej - pozytywizmu „wyrafinowanego”. 


\section{Podstawowe tezy dzisiejszego pozytywizmu prawniczego}

Współcześnie pozytywizm prawniczy stał się najbardziej płodnym kierunkiem w rozważaniach wokół najważniejszych pojęć prawa. Za jedną z jego największych zalet uznają dzisiejsi zwolennicy tego nurtu programowe nastawienie antymetafizyczne, gwarantujące uwolnienie od jakichkolwiek założeń filozoficznych, które mogłyby zagrażać legalizmowi prawniczemu i równości wobec prawa. ${ }^{3}$ Chociaż pozytywizm prawniczy nie jest odłamem pozytywizmu filozoficznego, czy filozofii analitycznej, to występuje między nimi wiele analogii; pozytywizm prawniczy nawiązuje $\mathrm{w}$ wielu miejscach do reguł metodologicznych obowiązujących na gruncie filozofii pozytywizmu. Z. Ziembiński, autor monografii poświęconej rozumieniu pojęć pozytywizm prawniczy i prawo natury, podkreśla, że w omawianiu tego pierwszego pojęcia przydatne są niekiedy odniesienia do pozytywizmu w różnych jego filozoficznych sensach tj.: minimalizmu założeń ontologicznych, nastawienia antyspekulatywnego, empiryzmu, scjentyzmu, nonkognitywizmu w metaetyce. ${ }^{4}$ Wśród cech pozytywizmu filozoficznego, mających pewne miejsca wspólne ze współczesnym pozytywizmem prawniczym, wymienić można paradygmat opierający się na intersubiektywności, czy też opierający się na uznawaniu zdań jako zdań analitycznych oraz skłonność do matematyzowania uzyskanych wyników. ${ }^{5}$

Termin ,pozytywizm prawniczy” rozumiany może być dzisiaj bardzo szeroko; ${ }^{6}$ według Herberta L.A. Harta, jednego z koryfeuszy tego kierunku, ma on w literaturze anglosaskiej zastosowanie w odniesieniu do jednego lub więcej spośród następujących twierdzeń: 1) prawa ludzkie są rozkazami, 2) brak koniecznego związku między prawem a moralnością, czy też prawem takim, jakim jest, a takim, jakim powinno być, 3) studia nad pojęciami prawnymi stanowią kwestię o charakterze fundamentalnym i są różne od badań historycznych, socjologicznych oraz krytycznej oceny prawa z punktu widzenia moralności czy celów społecznych, 4) system prawny jest zamkniętym systemem logicznym, a dane rozstrzygnięcie może być zeń wywiedzione, w oparciu o określone wcześniej reguły, za pomocą narzędzi logicznych, 5) przekonania moralne nie mogą być dowodzone na podstawie racjonalnej argumentacji, świadectw lub dowodu. ${ }^{7}$ Pozytywiści kontynentalni uzupełnili to zestawienie o następujące konstatacje: 6) porządek prawny to porządek prawa stanowionego, 7) ustawa jest wyłącznym źródłem prawa, 8) ustawa jest wyrazem nieskrępowanej niczym woli suwerena, 9) prawnik podlega ustawie bezwarunko-

3 M. Zirk-Sadowski, Pozytywizm prawniczy a filozoficzna opozycja podmiotu i przedmiotu poznania, (w:) J. Stelmach (red.), Studia z filozofii prawa, Kraków 2001, s. 84.

Z. Ziembiński, O pojmowaniu pozytywizmu oraz prawa natury, Poznań 1993, s. 9.

Ibidem, s. 75-76.

Zob. L. Morawski, Główne problemy współczesnej filozofii prawa. Prawo w toku przemian, Warszawa 1999, s. $15-18$.

7 H.L.A. Hart, Pojęcie prawa, tłum. J. Woleński, Warszawa 1998, s. 399-400. 
wo. ${ }^{8}$ Tezy powyższe mają różną wagę, a w zależności od tego, którą (czy które) dana teoria głosi, mówić można o określonej wersji pozytywizmu.

Nieformalna, szeroka i „obiegowa” definicja pozytywizmu prawniczego może brzmieć następująco: pozytywistą jest każdy, kto, odnosząc się do pojęcia prawa, minimalizuje, neguje czy lekceważy rolę religii, podkreśla zaś rolę państwa i jego upoważnionych przedstawicieli. ${ }^{9}$ Według rozpowszechnionego poglądu pozytywista głosi, że prawo obowiązuje niezależnie od swej treści, także moralnej; pozytywizm prawniczy jest doktryną skierowaną przeciwko koncepcjom prawa natury, które uzależniają ważność prawa od spełniania przez nie podstawowych norm moralnych. Apologeci prawa natury powszechnie zarzucają pozytywistom tolerowanie każdego, nawet niemoralnego prawa, ci ostatni zaś wskazują na nieprzydatność praw moralnych dla oceny prawa państwowego, powołując się na mnogość systemów moralnych.

Na obecny kształt pozytywizmu prawniczego znaczący wpływ miały trzy fale ataków, jak w wieku XX nań przypuszczono. Autorami pierwszego wystąpienia przeciwko przypisywanej mu tezie, że stosowanie prawa ma polegać na prostym wnioskowaniu z norm prawnych, byli amerykańscy realiści z pierwszej połowy stulecia, drugi atak dotyczył - znów tylko przypisywanej pozytywizmowi - koncepcji, że norma prawna obowiązuje zawsze, bez względu na jej treść. Atak ostatni związany jest z głośnym wystąpieniem Ronalda Dworkina przeciwko poglądom wyrażonym w Pojęciu prawa H.L.A. Harta, dotyczącym stosunku prawa i moralności.

Polemiki, wciąż jeszcze żywe, wywołane krytyczną wypowiedzią Dworkina doprowadziły do ukształtowania w obrębie pozytywizmu prawniczego dwóch stanowisk - pozytywizmu ,miękkiego" i „twardego”. Pierwsze z nich zakłada, że istniejące faktycznie systemy prawne przejmują wartości moralne, które stanowią kryteria obowiązywania prawa, stanowisko drugie broni tezy o całkowitej niezależności systemu prawa i moralności. ${ }^{10}$ Polemiki zogniskowane wokół podstawowych założeń „miękkiej” wersji pozytywizmu stanowią dziś najżywiej toczoną dyskusję w brytyjskiej teorii prawa.

Pierwsza z konstytuujących dzisiejszy pozytywizm prawniczy tez to „teza o źródłach", wedle której o tym, co w danej społeczności jest prawem, decyduje konwencja, fakt społeczny. Zgodnie z powyższą tezą źródłem prawa nie jest „natura” wyznaczająca jego „konieczną” treść; prawo ma proweniencję ludzką - decyduje o nim określone, takie a nie inne, zachowanie się jednostek. O istnieniu i kształcie prawa rozstrzyga istnienie powszechnej praktyki rozpoznawania i przyjmowania pewnych norm jako norm prawnych. Druga fundamentalna teza współczesnego

Zob. J. Stelmach, R. Sarkowicz, Filozofia prawa XIX i XX wieku, Kraków 1999, s. 23-24.

J. Boyle, Thomas Hobbes and the invented tradition of positivism: reflections language, power, and essentialism, na: http://www.law.duke.edu/boylesite/hobbes.htm (data dostępu: 1 grudnia 2014 r.)

T. Pietrzykowski, „Miękki” pozytywizm i spór o regułę uznania, (w:) J. Stelmach (red.), Studia z filozofii prawa, op. cit., s. 97-99. 
pozytywizmu prawniczego głosi, że nie istnieje konieczny, immanentny związek między prawem a moralnością - i choć pozytywiści dostrzegają rozmaite interakcje norm obu tych systemów, podkreślają, że związki te mają charakter przygodny, faktyczny a nie konieczny. Prawo dla swego istnienia nie potrzebuje ugruntowania w moralności, jest systemem autonomicznym. ${ }^{11}$

Do sformułowania obu tez przyczynił się H.L.A. Hart, tę ostatnią ugruntowała dyskusja przez niego wywołana; istotnym charakterystycznym rysem hartowskiej teorii prawa było sformułowanie ,minimum treści prawa natury"12 - ponieważ prawo i moralność regulują ten sam obszar ludzkiej aktywności i mają wspólne cele, każdy system prawny winien uwzględniać pewne, wynikające z natury ludzkiej uwarunkowania i respektować reguły chroniące zdrowie i życie jednostki, własność oraz zapewniające funkcjonowanie danego społeczeństwa. ${ }^{13}$

Hart uznał, że przetrwanie biologiczne jest podstawowym imperatywem rządzącym zachowaniem człowieka i podkreślał konieczność zrzeczenia się, na rzecz sprawujących władzę, części swoich uprawnień - dla ochrony życia i zdrowia. Brytyjski filozof, omawiając wzajemną relację systemów prawa i moralności (oba te pojęcia niosą „otwartą tekstowość”, w związku z czym ich wyjaśnianie wiąże się z licznymi problemami), dostrzega szereg różnego rodzaju związków między nimi. Istotne jednak, że w tym punkcie swojej filozofii prawa podkreśla Hart wagę różnicy zachodzącej miedzy systemem nakazów moralnych a systemem prawnym, ${ }^{14}$ co stawia go zdecydowanie po stronie pozytywistów prawnych; prawo obowiązuje wyłącznie wówczas, gdy ustanowione zostanie przez uprawniony podmiot w odpowiedniej, przewidzianej formie i procedurze. ${ }^{15}$

\section{Zarzuty Ronalda Dworkina}

Najgłośniejszy krytyk pozytywizmu prawniczego ostatnich lat, Ronald Dworkin, którego wczesne teksty korespondują jeszcze z hasłami pozytywizmu, w swojej argumentacji przeciwko jego tezom wskazuje na praktykę korzystania przez sądy w trakcie wydawania orzeczeń z ,zasad prawnych”, które nie są umocowane w systemie prawnym za pomocą reguły uznania. Owe zasady (principles), oparte na społecznych strukturach normatywnych, stanowią bardzo szczególne standardy postępowania, dla respektowania których podstawą są wartości moralne, np. sprawiedliwość, słuszność, czy uczciwość. Zarówno zasady, jak i reguły (rules) są nor-

Ibidem, s. 99-100.

H.L.A. Hart, Pojęcie prawa, op. cit., s. 233.

Ibidem, s. 261-269.

Ibidem, s. 233.

Odpór twierdzeniom tych badaczy filozofii Harta, którzy uznawać go chcieli za przedstawiciela nurtu naturalno-prawnego daje fakt, że sam Hart uważał się za pozytywistę, tyle że nie skrajnego, za pozytywistów skrajnych miał on Austina i Kelsena, zob. P. Kamela, Prawo i moralność w koncepcjach H.L.A. Harta, Toruń 2008, s. 171183 i J. Woleński, Wprowadzenie do H.L.A. Hart, Eseje z filozofii prawa, Warszawa 2001, s. XXI. 
mami postępowania, reguła jest kompletna i ścisła, w odróżnieniu od reguł, zasady mają charakter bardziej pojemny i niedookreślony, wiele reguł może wynikać z tej samej zasady. Istotne, że zasady funkcjonują zwykle poza prawem, nie wyznaczają rozstrzygnięcia organu stosującego prawo, mają też różną ,moc” (inaczej niż reguły, które działają z mocą jednakową) i tworzą w konkretnej sytuacji hierarchię - pewne $\mathrm{z}$ nich mają wagę większą od innych. ${ }^{16} \mathrm{Gdy}$ dana zasada w powszechnej ocenie uznawana jest za nieobowiązującą nie jest natychmiast (jak reguła) wyłączana z systemu prawnego, podlega raczej „erozji” albo ewoluuje wraz z całym systemem. ${ }^{17}$ Sądy, zwłaszcza w tzw. hard cases, trudnych, problematycznych, budzących wątpliwości sprawach, orzekają w oparciu o wspomniane zasady, kierując się ich treścią (a nie faktem ich formalnego "umocowania” w systemie prawnym) i tym, że pozwalają rozstrzygnąć w sposób „słuszny”.

Wedle Dworkina ,zasady prawne” często nie znajdują bezpośredniego uzasadnienia w przepisach, nie tylko w systemach common law, ale także w systemach prawa stanowionego, a mimo to „działają” jak tradycyjne reguły prawne usankcjonowane wprost $\mathrm{w}$ obowiązującym prawie; sędziowie uznają powyższe reguły za wiążące. ${ }^{18}$ Dowód na to, że dana zasada jest zasadą prawną odnaleźć można właśnie w jej ,instytucjonalnym poparciu”, objawiającym się na przykład wskazywaniem na nią przez sądy jako na podstawę rozstrzygnięć. Istotne, zdaniem Dworkina, jest to, że w odniesieniu do zasad nie sprawdza się podstawowa pozytywistyczna teza; nie działa tutaj hartowska „reguła uznania”. Odrzucić też należy, ze względu na funkcjonowanie zasad prawnych i rolę ,instytucjonalnego poparcia”, drugą tezę pozytywizmu, dotyczącą rozdziału prawa i moralności.

Ronald Dworkin, ,wojujący” antypozytywista, argumentuje, że w każdej sprawie można wskazać rozwiązanie jedynie słuszne (stanowisko ,wewnętrznego sceptycyzmu norm"19), a tym, co powoduje rozbieżności w ocenie danego problemu przez różnych sędziów, jest brak właściwych technik orzekania (brak także sędziom umiejętności argumentacyjnych, zaś jako grupa stanowią oni bardzo niedoskonałą wspólnotę komunikacyjną). Możliwość wskazania jedynego słusznego orzeczenia istnieje, wedle Dworkina, dzięki otwartości systemu i funkcjonowaniu zasad prawnych. Co istotne, interpretacja systemu prawa ma wtedy charakter twórczy; zasady nie są wszak, jak reguły, stosowane, ale w danej sprawie „,ważone”; prawo nie jest tworem gotowym w momencie podpisania aktu legislacyjnego. Zadanie sędziów jest więc niezmiernie istotne, a oni sami stają w koncepcji Dworkina w centrum kultury

16 M. Zirk-Sadowski, Pozytywizm prawniczy a filozoficzna opozycja podmiotu i przedmiotu poznania, (w:) J. Stelmach (red.), Studia z filozofii prawa, op. cit., s. 89-90.

17 P. Kamela, Prawo i moralność w koncepcjach H.L.A. Harta, op. cit.; T. Pietrzykowski, „Miękki” pozytywizm i spór o regułę uznania, (w:) J. Stelmach (red.), Studia z filozofii prawa, op. cit., s. 94-95. T. Pietrzykowski, „Miękki” pozytywizm i spór o regułę uznania, (w:) J. Stelmach (red.), Studia z filozofii prawa, op. cit., s. 100.

19 A. Kozak, Trzy modele praktyki prawniczej, (w:) J. Stelmach (red.), Studia z filozofii prawa, t. 2, op. cit., s. $156-157$. 
prawnej - winni poszukiwać najlepszego rozumienia prawa przy uwzględnieniu całokształtu struktur normatywnych danej społeczności. ${ }^{20}$

\section{Próby obrony doktryny - odpowiedź pozytywistów}

Problem „zasad prawnych” dostrzeżony przez Dworkina spotkał się z szerokim oddźwiękiem obrońców pozytywizmu prawniczego. Rolf Sartorius na przykład przyznaje, że normy o charakterze etycznym stają się prawem obowiązującym, ale nie ze względu na ich treść, ale z uwagi na to, że spełniają regułę pochodzenia, tj. pochodzą od uprawnionego organu normotwórczego. Sartorius zarzuca Dworkinowi, że nie przedstawił przekonywujących dowodów na rzecz tezy, że sądy stosując zasady prawne w hard cases, korzystają z nich ze względu na treść, a nie pochodzenie.

Z kolei przedstawiciele „miękkiego” pozytywizmu są gotowi uznać, że normy etyczne stają się czasem prawem nie z uwagi na pochodzenie, ale na podstawie kryterium treści, twierdzą też, uchylając krytykę Dworkina, że nie stoi to w sprzeczności z pozytywistycznym ,wyznaniem wiary”, dwoma kanonicznymi twierdzeniami pozytywizmu prawniczego: że obowiązywanie prawa jest niezależne od jego treści i że nie zależy też od wartościowania o charakterze etycznym. Tezą umożliwiającą zniesienie dworkinowskich zarzutów jest przyjęcie, że mająca charakter konwencjonalny (społeczny) reguła uznania może w sposób dowolny ustanawiać kryteria obowiązywania norm prawnych; mogą to być (ale wcale nie muszą) kryteria pochodzenia przepisów, innym możliwym kryterium jest ich treść.

Sednem koncepcji „miękkiego” pozytywizmu jest założenie, że samo wskazanie kryteriów obowiązywania prawa jest kwestią konwencji obowiązującej w danej społeczności, zaś konkretne kryteria i ich charakter nie są sprawą o charakterze pierwszorzędnym, gdy chodzi o definiowanie pojęcia prawa. Na gruncie omawianej koncepcji za prawo można uznać normy pochodzące od danego autorytetu, normy czyniące zadość wymogom treściowym - tam, gdzie takie kryterium przyjęto, a także normy, które są przyjmowane na mocy reguły uznania zakładającej oba wyżej wymienione rodzaje kryteriów (warunkiem uznania jest zgodność z przyjętą wcześniej w danej społeczności konwencją). Najistotniejszym punktem argumentacji „miękkich” pozytywistów jest wskazanie, że nadanie regułom moralnym rangi możliwego kryterium reguły uznania nie stoi w sprzeczności z drugą kanoniczną tezą pozytywizmu prawniczego, dotyczącą rozdziału pomiędzy prawem a moralnością; wartości moralne mogą stanowić kryterium reguły uznania, ale brak tu związku o charakterze koniecznym. ${ }^{21}$

\footnotetext{
20 Zob. M. Zirk-Sadowski, Pozytywizm prawniczy a filozoficzna opozycja podmiotu i przedmiotu poznania, (w:) J. Stelmach (red.), Studia z filozofii prawa, op. cit., s. 87-93.

21 Ibidem, s. 101-109.
} 
Interesujący wydaje się spór wiedziony w gronie samych pozytywistów - spór pomiędzy przedstawicielami „miękkiego” i „twardego” pozytywizmu; ci ostatni próbują wykazać, że zwolennicy koncepcji ,miękkiego” pozytywizmu nie są w istocie pozytywistami, a ich założenia pozostają w sprzeczności z kanonicznymi zasadami omawianego kierunku. Joseph Raz, pozytywista „ortodoksyjny”, polemizując z jej wyznawcami, podkreśla, iż sednem zjawiska prawa jest jego władczość. Norma prawna ,żąda” określonego zachowania niezależnie od tego, czy jakieś inne względy (np. moralne) do niego właśnie skłaniają, a nawet - jak twierdzi Raz - roszczenie do powinnego zachowania się, zawarte w normie prawnej, swoją mocą „unieważnia" wszelkie inne racje skłaniające do takiego, a nie innego postępowania. Dyspozycje zawarte w normie należy wykonać bez względu na to, czy postąpiłoby się w określony w normie sposób wziąwszy pod uwagę wszystkie inne okoliczności.

Argumentacja powyższa pokazuje, że nie da się pogodzić władczej natury prawa z uzależnieniem uczynienia mu zadość (wykonania go) od jego oceny w kategoriach etycznych. ${ }^{22}$,Miękki” pozytywizm, który dopuszcza uzależnienie przyjęcia norm od ich oceny moralnej, pozostaje zatem w sprzeczności z podstawową tezą pozytywizmu prawniczego, głoszącą, że prawo jest instytucją władczą. W odpowiedzi na zarzuty Raza podnoszony jest argument następujący: uznanie władczego charakteru prawa nie musi wyłączać działania innych racji skłaniających do danego działania czy zaniechania.

Stanowisko „miękkich” pozytywistów spotkało się z podobną krytyką ze strony Scotta Shapiro, który punktem wyjścia tej krytyki uczynił hartowską tezę głoszącą, że prawo istnieje po to, by dostarczać ludziom wskazówek co do tego, jak powinni się zachowywać, a także by formułować standardy oceny postępowania jednostek. Reguła prawna to taka, która wskazówek tego rodzaju udziela; jej obowiązywanie musi, dowodzi Shapiro, czynić praktyczną różnicę w dochodzeniu człowieka do przekonania, jak w danej sytuacji ma się zachować. Gdy jakaś reguła tej różnicy nie czyni, nie może pretendować do rangi reguły prawnej. Na gruncie „miękkiej” reguły uznania, dopuszczającej jako kryterium uznawania reguł pierwotnych m.in. wartości moralne, rodzą się poważne trudności ze wskazaniem odpowiedniego sposobu zachowania się. I tak reguły prawne w systemie z ,miękką" regułą uznania nie czynią zadość postulatowi ,praktycznej różnicy”. ${ }^{23}$

Choć w świetle powyższych uwag podstawowa teza ,miękkiego” pozytywizmu, dotycząca potencjalnej różnorodności kryteriów uznawania reguł prawnych, jawi się jako dyskusyjna, to brak dotychczas dostatecznie mocnych podstaw do kategorycznego jej odrzucenia. I mimo że faktycznie kryterium pochodzenia w systemach prawnych zachodniego kręgu cywilizacyjnego jest najpowszechniejsze, to - teoretycznie - reguła uznania, odwołująca się przecież do konwencji przyjętej 
w danej społeczności, nie jest w sposób konieczny powiązana z tym właśnie kryterium uznawania norm prawnych. Pozytywizm prawniczy w wersji „miękkiej”, odwołujący się do zasad moralnych, w tym zasady słuszności, najbliższy jest, jak się wydaje, paradygmatowi powszechnie przyjmowanemu przez współczesnych prawników, dogmatyków i praktyków. Znamienne, że metamorfozy, jakie przeszedł pozytywizm prawniczy od czasu swych narodzin w dziewiętnastym stuleciu, sprawiają, że pierwsze intuicje, dotyczące trwałej separacji między terminami ,pozytywizm prawniczy” i „zasada słuszności” można obecnie odrzucić. 


\section{LEGAL POSITIVISM AND THE PRINCIPLE OF EQUITY}

The purpose of this article is to analyze the relationship between legal positivism and the principle of equity. A cursory examination of these two concepts can lead to the conclusion that the answer to the question of the existence of a relationship between them can only be negative. Classic legal positivism is in fact directed against the concept of natural law that links the validity of the laws with the fulfillment by them basic moral standards. However, modern positivism occurs in two clearly different guises. „Soft” legal positivism assumes that the legal systems take the moral values, including principle of equity, which are the criteria of the law. The indication within the legal positivism of his „,soft" version alleviates acute dichotomy ,positive law” - ,natural law”.

Keywords: natural law, moral values, the determinants of legal positivism, „soft” legal positivism and „hard” legal positivism, Ronald Dworkin's criticism of legal positivism, legal principles and legal rules, open texture of law, „hard cases” 